JUANG: Jurnal Wahana Konseling (Vol. 2, No. 1, Maret 2019)

\title{
BUDAYA ADIL GENDER PADA PENDIDIKAN ANAK USIA DINI MELALUI BERMAIN PERAN
}

\author{
Ramtia Darma Putri \\ Universitas PGRI Palembang
}

Email: tyadhuarrma27@gmail.com

\begin{abstract}
ABSTRAK
Perkenalan terhadap masalah gender selayaknya dilakukan sedini mungkin. Hal ini penting karena berkaitan erat dengan tugas perkembangan sosial yang harus dilewati oleh anak usia dini yaitu mempelajari tentang perbedaan jenis kelamin agar sesuai dengan apa yang diharapkan. Namun seiring dengan adanya perubahan sosial yang terjadi pada masyarakat, peran gender tidak lagi secara khusus dikaitkan dengan jenis kelamin seseorang. Identitas gender maupun peran gender lebih difungsikan akibat pengaruh sosial baik dalam sosialisasi, hasil interaksi sosial maupun proses rekognisi dari sejumlah pengetahuan yang dimiliki seseorang. Beberapa alternatif pemecahan masalah yang mungkin dapat diterapkan dalam mengatasi kesalahpahaman mengenai gender. Khusus pada dunia pendidikan, Budaya adil gender pada anak usia dini akan berlangsung secara optimal dan efektif bila direncanakan dengan baik dan metode yang tepat. Untuk itu guru perlu merencanakan dengan matang salah satu strategi adil gender yaitu melalui bermain peran. Melalui metode bermain peran, anak diharapkan dapat mengenali jati dirinya sendiri serta mendapatkan kesempatan untuk mengembangkan fantasi dan menyalurkan kecenderungan pembawaannya sesuai dengan pengalaman dan kegiatan dalam kehidupan sehari-hari.
\end{abstract}

Kata Kunci: Budaya Adil Gender, Pendidikan Anak Usia Dini, Bermain Peran

\section{GENDER FAIR CULTURE IN EDUCATIONAL CHILDREN IS EARLY THROUGH ROLE PLAY}

\begin{abstract}
Introducing gender issues should be done as early as possible. This is important because it is closely related to the task of social development that must be passed by early childhood, which is to learn about gender differences to suit what is expected. But along with the social changes that occur in society, gender roles are no longer specifically associated with one's gender. Gender identity and gender roles are more functioned due to social influence both in socialization, the results of social interaction and the process of recognition of the amount of knowledge a person has. Some alternative solutions to problems that might be applied in overcoming misunderstandings about gender. Especially in the world of education, gender fair culture in early childhood will take place optimally and effectively if it is well planned and the right method. For this reason, the teacher needs to carefully plan one gender
\end{abstract}


fair strategy through role playing. Through the role playing method, children are expected to be able to recognize themselves and get an opportunity to develop fantasies and channel their propensity according to their experiences and activities in daily life

\section{Keywords: Gender Fair, Early Childhood, Role Playing}

\section{PENDAHULUAN}

Permendiknas No 84 Tahun 2008 tentang Pedoman Pelaksanaan Pengarusutamaan Gender (PUG) Bidang Pendidikan menjelaskan bahwa peningkatan kesetaraan dan keadilan gender di bidang pendidikan sangat penting dilakukan agar lebih menjamin semua warga negara baik laki-laki maupun perempuan dapat mengakses pelayanan pendidikan, berpartisipasi aktif, dan mempunyai kontrol serta mendapat manfaat dari pembangunan pendidikan, sehingga laki-laki dan perempuan dapat mengembangkan potensinya secara maksimal. Berdasarkan penjelasan tersebut, secara rasional menggambarkan bahwa laki-laki dan perempuan memiliki kesetaraan namun tidak menghilangkan kodratnya sebagai makhluk dengan idenditas gendernya. Hal ini sejalan dengan tujuan dari Millenium Development Goals (MDG) yaitu mendorong kesetaraan gender dan pemberdayaan perempuan dengan menghapus kesenjangan gender. Untuk mencapai target tersebut, salah satunya dengan meningkatkan kemampuan kelembagaan pendidikan dalam mengelola danmempromosikan pendidikan berwawasan gender sehingga dapat meningkatkan pemahaman masyarakat tentang kesetaraan gender.

Lebih lanjut, dalam permendiknas ini terungkap bahwa dalam hal akses penduduk laki-laki dan perempuan sudah memiliki peluang yang hampir setara untuk mendapatkan layanan pendidikan. Namun demikian kesenjangan gender dalam proses pembelajaran masih terjadi di beberapa daerah, seperti (1) materi bahan ajar yang pada umumnya masih bias gender; (2) proses pembelajaran di kelas yang belum sepenuhnya mendorong partisipasi aktif secara seimbang antara siswa laki-laki dan perempuan; dan (3) lingkungan fisik sekolah yang belum menjawab kebutuhan spesifik anak laki-laki dan perempuan. Disamping itu pengelolaan pendidikan juga perlu dilaksanakan kearah adil gender atau memberikan peluang yang seimbang bagi laki-laki dan perempuan untuk berpartisipasi dalam proses pengambilan keputusan. 
Selain itu, stigma yang berkembang dimasyarakat juga ternyata mempengaruhi masih berlangsungnya bias gender. Indarni (2012) menjelaskan bahwa sekolah dan guru memiliki bias terhadap anak laki-laki dan perempuan. Beberapa bukti menunjukkan bahwa di kelas terjadi bias gender terutama terhadap laki-laki, salah satunya anak laki-laki sering dianggap nakal. Kepatuhan, mengikuti aturan, kerapian dan teratur biasanya sangat dihargai dan berusaha ditegakkan di dalam kelas, biasanya lebih mengkarakteristikkan anak perempuan daripada laki-laki. Pendidikan yang bias gender dapat melabel anak laki-laki sebagai anak yang berkerja di publik, bersifat kuat, pemberani, nakal, dan sifat-sifat maskulin lainya, sedangkan perempuan dianggap cocok berkerja dibagian domestik, bersifat lemah, penakut, mematuhi aturan dan sifatsifat feminin lainnya.

Perkenalan terhadap masalah gender selayaknya dilakukan sedini mungkin. Hal ini penting karena berkaitan erat dengan tugas perkembangan sosial yang harus dilewati oleh anak usia dini yaitu mempelajari tentang perbedaan jenis kelamin agar sesuai dengan apa yang diharapkan.

\section{PERKEMBANGAN ANAK USIA DINI}

\section{a. Pengertian Anak Usia Dini}

Menurut Direktorat Pendidikan Anak Usia Dini (2004) anak usia dini adalah anak yang berada pada usia 0-6 tahun. Usia dari kelahiran hingga enam tahun merupkan usia kritis bagi perkembangan semua anak, tanpa memandang dari suku atau budaya anak berasal. Stimulasi yang diberikan pada anak usia dini akan mempengaruhi laju pertumbuhan dan perekembangan anak serta sikap dan perilaku sepanjang rentang kehidupannya. Lebih lanjut, Masitoh (2009) menggambarkan anak usia dini merupakan sekelompok anak yang berada dalam proses pertumbuhan dan perkembangan yang bersifat unik, artinya memiliki karakteristik pertumbuhan dan perkembangan fisik, motorik, kognitif atau intelektual, sosialemosional, serta bahasa. 


\section{b. Ciri-ciri Anak Usia Dini}

Kartono (dalam Syaodih \& Agustin, 2013) mengungkapkan ciri anak usia dini yaitu bersifat egosentris naif, relasi sosial yang primitif, kesatuan jasmani dan rohani yang hampir tidak terpisahkan, dan sikap hidup yang fisiognomis.

\section{c. Aspek-aspek Perkembangan Anak Usia Dini}

Aspek perkembangan yang dialami anak usia dini meliputi aspek fisik motorik, kognitif, bahasa, sosial emosional, emosi, seni, dan nilai-nilai moral dan agama.

1. Perkembangan fisik motorik

Pertumbuhan fisik pada masing-masing anak tentu berbeda-beda. Pada usia dini, pertumbuhan tinggi dan berat badan relatif seimbang dan terjadi secara bertahap. Seiring perubahan fisik yang semakin matang, maka perkembangan motorik anak juga semakin terkoordinasi dengan baik. Misalkan pada anak usia 1 tahun masih belum terlalu lancar dalam berjalan, maka pada usia 2 tahun anak pada umumnya sudah dapat berlari.

2. Perkembangan kognitif

Perkembangan kognitif berkaitan dengan perkembangan perkembangan berpikir. Perkembangan kognitif pada anak usia dini berlangsung menurut urutan yang sama pada setiap anak. Piaget (dalam Syaodih \& Agustin, 2013) menjelaskan perkembangan kognitif pada anak terjadi dalam empat tahapan, yaitu : (1) tahapan sensorimotorik yang terjadi pada usia 0-2 tahun; (2) tahapan praoperasional yang terjadi pada usia 2-7 tahun; (3) tahapan operasional konkrit yang terjadi pada usia 7-11 tahun; dan (4) tahapan operasional formal yang terjadi pada usia 11-16 tahun.

3. Perkembangan bahasa

Pada usia 4-6 tahun, anak memiliki kemampuan bahasa yang berkembang sejalan dengan rasa ingin tahunya. Anak sudah dapat mengucapkan kalimatkalimat pendek dan akan bertambah seiring bertambahnya usia anak.

4. Perkembangan sosial emosional 
Perkembangan sosial pada anak biasanya akan dipengaruhi oleh kesempatan bergaul, minat dan motivasi, bimbingan dari orangtua, dan adanya kemampuan berkomunikasi. Hurlock (dalam Syaodih \& Agustin, 2013) menjelaskan proses sosialisasi yang harus dilakukan individu yaitu dengan belajar berperilaku yang dapat diterima secara sosial, memainkan peran sosial yang dapat diterima, dan perkembangan sikap sosial itu sendiri.

5. Perkembangan emosi

Perkembangan emosi biasanya muncul lebih awal dibandingkan dengan perkembangan sosial ataupun kognitif. Hurlock (dalam Syaodih \& Agustin, 2013) menjelaskan karakteristik emosi anak biasanya ditampakkan dalam bentuk emosi yang kuat, sering, bersifat sementara, individualitas, berubah kekuatannya, dan ditampakkan dalam bentuk perilaku.

6. Perkembangan seni

Kemampuan anak usia dini dalam merasakan dan melalukan berbagai keterampilan seninya dapat dikembangkan melalui pelatihan dan bimbingan yang terarah dan disesuaikan dengan proses belajar anak yaitu belajar sambil bermain.

7. Perkembangan nilai-nilai moral dan agama Perkembangan nilai dan moral pada ana memang harus dikenalkan sejak dini. Contoh dan arahan perlu diberikan dari orang terdekat agar dapat menjadi kebiasaan yang baik bagi diri anak. Pemberian pengarahan dalam bidang spiritual akan membuat moral anak berkembang sehingga ia dapat memilih tindakan yang baik yang sesuai dengan nilai dan moral yang berlaku.

\section{KONSEP GENDER}

Menurut Woman's Studies Encyclopedia (Umar, 2003) bahwa yang dimaksud dengan gender adalah suatu konsep kultural yang berupaya membuat pembedaan (distinction) dalam hal peran, perilaku, mentalitas, dan karakteristik emosional antara laki-laki dan perempuan yang berkembang dalam masyarakat. Selanjutnya, KPP (2004) menjelaskan gender adalah perbedaan peran, fungsi, persifatan, kedudukan, 
tanggung jawab dan hak perilaku, baik perempuan, maupun laki-laki yang dibentuk, dibuat, dan disosialisasikan oleh norma, adat kebiasaan, dan kepercayaan masyarakat setempat. Konsep gender berhubungan dengan peran dan tugas yang pantas/tidak pantas, baik untuk laki-laki, maupun perempuan.

Santrock (2002:280) menjelaskan gender mengacu pada dimensi sosial yang melekat pada jenis kelamin seseorang. Membicarakan gender tidak terlepas dari istilah identitas dan peran gender. Santrock (2002) kemudian menjelaskan bahwa identitas gender adalah rasa seseorang sebagai laki-laki atau perempuan, yang diperoleh dari sebagian besar anak-anak pada waktu mereka usia 3 tahun. Hal serupa diungkapkan oleh Papalia, dkk (2011) bahwa identitas gender merupakan kesadaran seseorang tentang gendernya dan juga orang lain, menurut jenisnya hingga antara usia 2-3 tahun.

Peran gender sendiri, menurut Papalia, dkk (2011) menyebutkan bahwa peran gender adalah perilaku, perhatian, sikap, keterampilan dan pertimbangan ciri kepribadian sosial yang tepat dari laki-laki atau perempuan. Berbeda dengan pendapat di atas, Santrock (2002) menyebutkan bahwa peran gender merupakan sebuah harapan yang berisi tentang bagaimana seharusnya seorang laki-laki atau perempuan itu berpikir, bertindak, dan merasa.

Beberapa hal yang mempengaruhi perkembangan gender anak seperti faktor hormon dan keturunan, pengaruh sosial yang terdiri atas pola asuh, psikoanalisisnya, teman sebaya, sekolah dan guru, media elektronik. Selain itu juga ada faktor kognitif anak yang dapat mempengaruhi daya pikirnya tentang peran gender (Santrock, 2007).

\section{BUDAYA ADIL GENDER PADA PENDIDIKAN ANAK USIA DINI}

Anak belajar melalui mengimitasi dan mengasimilasi dari perilaku maupun konsep-konsep konkrit yang diperoleh dari aktivitas bermain, belajar di PAUD, maupun bersosialisasi dengan teman sebaya juga orang dewasa lain. Perkembangan dan konstruksi identitas gender anak dalam berbagai segi kehidupan merupakan bagian dari dasar pihak PAUD dalam merancang kurikulum berbasis gender, khususnya berupa aktivitas-aktivitas yang mampu mengonstruksi pengetahuan anak mengenai gender. Dalam memberikan pendidikan gender bagi anak usia dini, perlu 
memperhatikan beberapa hal. Santrock (2002) menjelaskan beberapa faktor yang mempengaruhi pemberian pendidikan gender pada anak usia dini, yaitu (1) pengaruh biologis; (2) pengaruh sosial; dan (3) pengaruh kognitif.

Indarni (2012) mengungkapkan terdapat perhatian khusus bahwa sekolah dan guru memiliki bias terhadap anak laki-laki dan perempuan. Beberapa bukti menunjukkan bahwa di kelas terjadi bias gender terutama terhadap laki-laki, salah satunya anak laki-laki sering dianggap nakal. Sikap patuh, mengikuti aturan, kerapian dan teratur biasanya lebih mengkarakteristikkan anak perempuan daripada laki-laki. Pendidikan yang bias gender dapat melabel anak laki-laki sebagai anak yang berkerja di publik, bersifat kuat, pemberani, nakal, dan sifat-sifat maskulin lainya, sedangkan perempuan dianggap cocok berkerja dibagian domestik, bersifat lemah, penakut, mematuhi aturan dan sifat-sifat feminin lainnya.

Namun seiring dengan adanya perubahan sosial yang terjadi pada masyarakat, peran gender tidak lagi secara khusus dikaitkan dengan jenis kelamin seseorang. Identitas gender maupun peran gender lebih difungsikan akibat pengaruh sosial baik dalam sosialisasi, hasil interaksi sosial maupun proses rekognisi dari sejumlah pengetahuan yang dimiliki seseorang. Peran orangtua tidak kalah penting dalam memperkenalkan peran gender pada anak-anaknya. Berdasarkan hasil penelitian Wardhani (2017) mengungkapkan terdapat 43 orang tua $(43,43 \%)$ berada pada kategori konstruktif, di mana orang tua dalam kategori ini berpendapat bahwa anak harus dikontrol dalam proses identifikasi jenis kelamin dan memahami peran gender melalui kegiatan atau pun kontrol orang tua untuk pada kegiatan-kegiatan tertentu. Kelompok orang tua ini terlibat penuh dalam menentukan pemilihan sekolah, pemilihan alat bermain, kegiatan atau tugas rumah yang dapat dikerjakan anak, pemilihan baju dan pemilihan teman bermain. orang tua konstruktif, yaitu kelompok orang tua yang berpendapat bahwa penting mengenalkan jenis kelamin anak dan peran yang melekat pada identitas gendernya tersebut.

Lantas bagaimana implikasi terhadap penyesuaian kurikulum PAUD dan hasil penelitian ini? Proses konstruksi identitas merupakan bentuk pengetahuan baru anak terhadap identitas dirinya yang dapat dibangun melalui aktivitas bersama dalam 
lingkungan sosial maupun fisik. Pengenalan awal kemampuan anak untuk mengidentifikasi individu merupakan tanda bahwa anak mengenali adanya perbedaan dan persamaan antara dirinya dengan orang lain. Aktivitas bermain bersama teman yang terjadi setiap hari di PAUD merupakan kegiatan lain yang membantu anak dalam mengonstruksi pengetahuan akan identitas gendernya. Alat bermain, jenis permainan, maupun teman bermain yang dipilih merupakan pengalaman unik yang terkadang bersifat individual merupakan bagian dari proses sosialisasi. Salah satu strategi yang dirasakan tepat dalam mengenalkan konsep gender pada anak usia dini adalah dengan bermain peran.

\section{BERMAIN PERAN}

Bermain peran disebut juga bermain simbolik, bermain pura-pura, makebelieve, imajinasi. Permainan ini sangat penting untuk perkembangan kognisi, sosial dan emosi pada anak. Bermain peran, membolehkan anak untuk membayangkan dirinya ke masa depan dan menciptakan kondisi masa lalu (Madyati, 2016:156). Lebih lanjut, Shoimin (2014:161) menjelaskan Metode bermain peran ini dapat memberikan kesempatan kepada anak untuk praktik menempatkan diri mereka dalam peran-peran dan situasi-situasi yang akan meningkatkan kesadaran terhadap nilai nilai dan keyakinan-keyakinan mereka sendiri dan orang lain.

Bermain peran bagi anak usia dini dirasakan memiliki manfaat yang baik bagi perkembangan anak usia dini sendiri, termasuk apabila ditinjau dari manfaat keadilan gendernya, antara lain: (1) membangun kepercayaan diri anak; (2) mengembangkan

kemampuan bahasa; (3) meningkatkan kreativitas; (4) memberikan kesempatan untuk memcahkan masalah; (5) membangun kemampuan sosial; dan (6) membantu memberikan pandangan yang positif.

Bermain peran memiliki kelemahan dan kelebihan. Shoimin (2014:162-163) menjelaskan beberapa kelemahan dan kelebihannya adalah sebagai berikut:

a. Kelebihan

1. Anak bebas berekspresi dan mengambil keputusan. 
2. Permainan merupakan penemuan yang mudah dan dapat digunakan dalam situasi dan waktu yang berbeda.

3. Guru dapat mengevaluasi pengalaman anak melalui pengamatan saat permainan.

4. Dapat membuat kesan bagi anak dan tahan lama dalam ingatan.

5. Sangat menarik bagi anak sehingga memungkinkan kelas menjadi dinamis dan penuh antusias.

6. Membangkitkan gairah dan semangat optimis dalam diri anak, serta menumbuhkan rasa kebersamaan dan kesetiakawanan sosial.

7. Dapat menghayati peristiwa yang berlangsung dengan mudah dan memetik butir-butir hikmah yang terkandung didalamnya.

b. Kelemahan

1. Metode bermain peran memerlukan waktu yang relatif panjang.

2. Memerlukan kreativitas dan daya kreasi yang tinggi dari pihak guru maupun murid.

3. Kebanyakan anak yang ditunjuk sebagai pemeran merasa malu untuk melakukan suatu adegan.

4. Apabila permainan sosiodrama dan bermain peran mengalami kegagalan, bukan saja dapat memberi kesan kurang baik, tetapi sekaligus berarti tujuan pengajaran tidak tercapai.

5. Tidak semua materi pelajaran dapat disajikan melalui metode bermain peran.

\section{PEMBAHASAN}

Masalah mengenai gender dirasakan masih menjadi bagian yang sulit untuk dapat dipecahkan. Hal ini dimungkinkan karena gender erat kaitannya dengan pemahaman masyarakat yang telah mengakar dan berujung pada pemahaman yang keliru mengenai konsep gender itu sendiri. Beberapa alternatif pemecahan masalah yang mungkin dapat diterapkan dalam mengatasi kesalahpahaman mengenai gender ini antara lain, mengajak anak untuk diskusi tentang apa yang mereka pahami dan buat anak agar tidak merasa dilarang ataupun dibatasi aktivitasnya. Selanjutnya, melatih 
anak untuk berpikir logis, misalnya ketika melarang anak untuk melakukan sesuatu, berikan alasan yang tepat mengapa hal itu tidak boleh dilakukan. Mengenalkan anak pada peran-peran yang bisa dilakukan baik untuk laki-laki maupun perempuan, misalnya mengajak anak berkebun, mengerjakan pekerjaan rumah, atau melihat berbagai profil pekerjaan yang bisa dimiliki oleh laki-laki maupun perempuan. Hal yang tidak kalah pentingnya adalah dengan menanamkan sikap menghormati dan menghargai anatar jenis kelamin.

Khusus pada dunia pendidikan, telah sama-sama kita ketahui bahwa pelaksanaan proses pembelajaran yang terjadi pada anak usia dini adalah dengan metode belajar sambil bermain. Beberapa upaya yang dilakukan guru dalam menerapkan pendidikan kesetaraan gender dapat dilihat dari rancangan pembelajaran, metode dan media yang digunakan di PAUD. Budaya adil gender pada anak usia dini akan berlangsung secara optimal dan efektif bila direncanakan dengan baik dan metode yang tepat. Untuk itu guru perlu merencanakan dengan matang salah satu strategi adil gender yang telah dijelaskan sebelumnya.

Hal-hal yang perlu dilakukan dan diperhatikan oleh guru dalam menerapkan strategi bermain peran bagi anak usia dini dapat dijelaskan sebagia berikut:

1. Pemanasan, yaitu kegiatan untuk memperkenalkan anak pada masalah yang mungkin mereka hadapai, seperti sopan santun terhadap orang tua, menghargai teman sekelas, dan lain sebagainya.

2. Memilih pemain, yaitu kegiatan di mana guru dan anak usia dini memilih karakter yang akan dimainkan anak. Kegiatan ini dapat dilaksanakan sesuai pilihan guru, usulan dari anak, atau cabut undian.

3. Menata panggung, yaitu kegiatan di mana guru dan anak usia dini akan berdiskusi di mana, bagaimana, dan apa saja yang diperlukan dalam memainkan perannya nanti.

4. Menyiapkan pengamat, yaitu kegiatan di mana guru akan menunjuk beberapa anak untuk mengamati peran yang dimainkan oleh teman-teman mereka. 
5. Memainkan peran, yaitu kegiatan permainan peran yang akan dilaksanakan secara spontan. Guru tidak perlu menyiapkan dialog sehingga anak dapat mengeksplor peran mereka sendiri.

6. Diskusi dan evaluasi, yaitu kegiatan di mana guru dan anak usia dini mendiskusikan permainan yang telah dilaksanakan terlebih pada peran-peran yang ditunjukkan.

7. Memainkan peran ulang, yaitu kegiatan mengulang kegiatan permainan peran yang sudah dilaksanakan sebelumnya sesuai dengan hasil diskusi dan evaluasi yang telah dilakukan, dengan harapan anak-anak menjadi lebih paham terhadap peran-peran yang dimainkan.

8. Diskusi dan evaluasi kedua, yaitu kegiatan evaluasi yang lebih diarahkan pada konteks realitas pada kehidupan sehari-hari.

9. Berbagi pengalaman dan kesimpulan, yaitu kegiatan di mana ank diajak untuk berbagi pengalaman tentang tema yang sesuai dengan permainan peran yang telah dilaksanakan sebelumnya. Pada saat membuat kesimpulan diharapkan anak-anak lebih memahami peran-peran yang telah ditampilkan dengan mengaitkannya pada kehiduan sehari-hari.

Melalui metode bermain peran, anak diharapkan dapat mengenali jati dirinya sendiri serta mendapatkan kesempatan untuk mengembangkan fantasi dan menyalurkan kecenderungan pembawaannya sesuai dengan pengalaman dan kegiatan dalam kehidupan sehari-hari.

\section{PENUTUP}

Pendidikan gender yang diberikan pada anak usia dini akan tercapai apabila disesuaikan dengan tahapan perkembangan fisik maupun psikologisnya termasuk didalamnya perkembangan kognitif anak. Pendidikan adil gender berkaitan erat dengan tugas perkembangan sosial yang harus dilewati oleh anak usia dini yaitu mempelajari tentang perbedaan jenis kelamin agar sesuai dengan apa yang diharapkan. Mengenalkan anak pada peran-peran yang bisa dilakukan baik untuk laki-laki maupun perempuan perlu melibatkan orangtua selain dengan memberikan pendidikan adil gender di sekolah melalui strategi bermain peran. 


\section{DAFTAR PUSTAKA}

Direktorat Pendidikan Anak Usia Dini 2994. Konsep Dasar Pendidikan Anak Usia Dini. Jakarta: Departemen Pendidikan Nasional.

Indarni, N. 2012. "Efektivitas Cerita Bergambar terhadap Pemahaman Peran Gender pada Anak di Taman Kanak-Kanak". Indonesian Journal of Early Childhood Education Studies, IJECES 1 (1) (2012).

Kementerian Pemberdayaan Perempuan (KPP) "Bunga Rampai: Panduan dan Bahan Pembelajaran Pelatihan Pengarusutamaan Gender dalam Pembangunan Nasional," (Kerjasama Kementerian Pemberdayaan Perempuan RI, BKKBN, dan UNFPA, 2004.

Madyawati, L. 2016. Strategi Pengembangan Bahasa Pada Anak. Jakarta: Kencana

Masitoh. 2009. Strategi Pembelajaran TK. Jakarta: Universitas Terbuka.

Papalia, Diane E, Wendkos, S, Olds, dan Feldman, R.R. 2001. Human Development. Boston: McGraw Hill.

Peraturan Menteri Pendidikan Nasional Nomor 84 Tahun 2008 tentang Pedoman Pelaksanaan Pengarusutamaan Gender Bidang Pendidikan.

Santrock, J.W. 2002. Life Span Development: Perkembangan masa hidup. Edisi 5, Jilid I. Jakarta: Erlangga.

Shoimin, A. 2014. 68 Model Pembelajaran Inovatif dalam Kurikulum 2013. Yogyakarta: Ar-Ruzz Media

Syaodih, E \& Agustin, M. 2013. Bimbingan Konseling untuk Anak Usia Dini. Tangerang Selatan: Universitas Terbuka.

Umar, N. (2003). “Discourse Gender Perspektif Al-Qur’an”. Pikiran Rakyat [online]. Tersedia: http://www.pikiranrakyat.com/cetak/0803/teropong/resensibuku1.htm [akses: 25 September 2006].

Wardhani, W.D.L. 2017. “Constructing Gender Identity In Early Children (A Survey Kabupaten Jember)". Prosiding Strengthening Local Communities Facing The Global Era, No 1 (2017). 